\title{
A Narrative Review on Therapeutic Potentials of Watercress in Human Disorders
}

\author{
Esmaeel Panahi Kokhdan $\mathbb{D D}^{1}$ Hadi Khodabandehloo $\mathbb{D}^{1}{ }^{2}$ Hossein Ghahremani $\left(\mathbb{D},{ }^{3}\right.$ \\ and Amir Hossein Doustimotlagh $\mathbb{D}^{1,4}$ \\ ${ }^{1}$ Medicinal Plants Research Center, Yasuj University of Medical Sciences, Yasuj, Iran \\ ${ }^{2}$ Department of Clinical Biochemistry, School of Medicine, Zanjan University of Medical Sciences, Zanjan, Iran \\ ${ }^{3}$ Department of Clinical Biochemistry, School of Medicine, Shahid Beheshti University of Medical Sciences, Tehran, Iran \\ ${ }^{4}$ Department of Clinical Biochemistry, Faculty of Medicine, Yasuj University of Medical Sciences, Yasuj, Iran
}

Correspondence should be addressed to Amir Hossein Doustimotlagh; amirhosseindoustimotlagh@gmail.com

Received 18 January 2021; Accepted 30 April 2021; Published 8 May 2021

Academic Editor: Armando Zarrelli

Copyright (c) 2021 Esmaeel Panahi Kokhdan et al. This is an open access article distributed under the Creative Commons Attribution License, which permits unrestricted use, distribution, and reproduction in any medium, provided the original work is properly cited.

\begin{abstract}
Watercress $(W C)$ is an aquatic vegetable that belongs to the Brassicaceae family, and it often grows near water. In traditional medicine, $W C$ is a known remedy for hypercholesterolemia, hyperglycemia, hypertension, arthritis, bronchitis, diuresis, odontalgia, and scurvy. It also acts as an antiestrogenic and can be used as a nutritional supplement. It has been reported that these therapeutic effects are due to primary metabolites such as isothiocyanates, glucosinolates, polyphenols (flavonoids, phenolic acids, and proanthocyanidins), vitamins $\left(\mathrm{B}_{1}, \mathrm{~B}_{2}, \mathrm{~B}_{3}, \mathrm{~B}_{6}, \mathrm{E}\right.$, and $\left.\mathrm{C}\right)$, terpenes (including carotenoids), and bioelements which exist in this plant. Many pharmacological studies confirm the antioxidant, antibacterial, anticancer, antipsoriatic, anti-inflammatory, cardioprotective, renoprotective, hepatoprotective, and antigenotoxicity effects of $W C$. The consumption of $W C$ extract can be useful in reducing the complications of hypercholesterolemia and hyperglycemia. Furthermore, the extract of WC could markedly augment the antioxidant enzymes such as superoxide dismutase and catalase activity. Interestingly, consumption of food rich in polyphenols such as WC extract can help reduce oxidative stress, DNA damage, and cancer susceptibility. Several studies also showed that $W C$ extract significantly reduced liver injury as a result of cholestatic hepatic injury, gamma radiation, arsenic, and acetaminophen-induced hepatotoxicity. In this review, the researchers focus on the phytochemical and biochemical characterizations of $W C$ and its therapeutic effects in the treatment of human diseases.
\end{abstract}

\section{Introduction}

Watercress (Nasturtium officinale L.) is an aquatic perennial leafy vegetable that is a member of the Brassicaceae family and it is usually found in and/or around water (Figure 1). Although this plant is native to western Asia, Europe, India, and Africa, its cultivation is not limited to these regions as it can grow anywhere on earth. Farmers used to plant WC in ponds, lakes, and slow-moving water like streams, rivers, and canals with moderately alkaline conditions. $W C$ has Latin equivalents such as Rorippa nasturtium aquaticum, Nasturtium aquaticum, and Rorippa officinalis. As a plant,
WC has recognized nutritional values but it seems that its biological properties suffer undue neglect $[1,2]$.

The traditional medicine of Azerbaijan, Iran, Morocco, and Mauritius western Asia, India, Europe, and Africa has made extensive uses of $W C[1,2]$. Turkish folk medicine used $W C$ as a drug for relieving abdominal pain. They also eat it as a vegetable and some even add it to their salads [3]. Iranian traditional medicine administered it as an antidiabetic agent, and Iranian people consumed it as an ingredient in their juices, salads, or other dishes [4]. Today, manufacturers have recognized the potential values of $W C$, so they use it to produce healthy foods and cosmetic products [1]. Watercress 


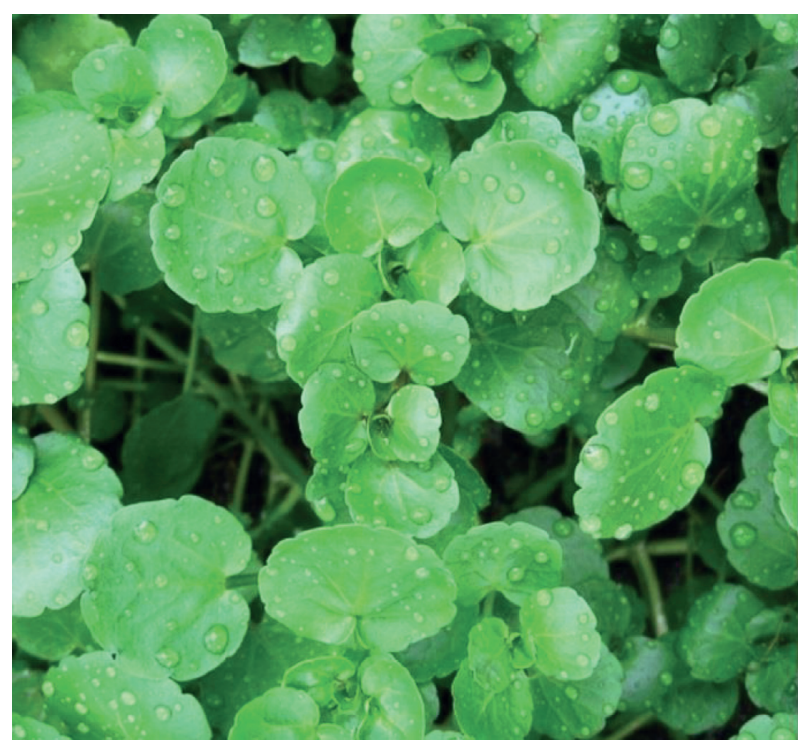

Figure 1: Watercress (Nasturtium officinale).

is consumed as fresh as possible, and it can be added to soups and other dishes. As a home remedy, the leaves of $W C$ can be used as diuretic, depurative, expectorant, odontalgic, and hypoglycemic agents [5]. Moreover, WC shows exquisite resilience in polluted soils and in polluted water that contains heavy metals [6]. The crude extract of $W C$ indicates high levels of antioxidant capacity in vitro. This extract also can inhibit the three stages of carcinogenesis including initiation, proliferation, and metastasis in cancer cell models that are present in vitro [7].

In traditional medicine, $W C$ is an effective drug in treating hypercholesterolemia, hypertension, hyperglycemia, asthma, arthritis, cough, catarrh of the respiratory tract, bronchitis, diuresis, influenza, scurvy, and tuberculosis. It is a known appetizer for digestion complaints and can be used as a nutritional supplement. It is also famous for its expectorant, odontalgic, and antiestrogenic activity $[1,8]$. In Germany, the $W C$ is an FDA-approved plant that can be used in phytotherapy, rhinitis, and homeopathic medicines [1]. These therapeutic effects can be ascribed to primary metabolites such as glucosinolates, polyphenols (flavonoids, phenolic acids, and proanthocyanidins), isothiocyanates, vitamins $\left(B_{1}, B_{2}, B_{3}, B_{6}, E\right.$, and $\left.C\right)$, terpenes (including carotenoids), and bioelements that exist in the plant. The most significant group of secondary metabolites that exist in the plant are glucosinolates $[1,9]$. It has been found that $W C$ leaves contain 14 phenolic compounds, i.e., gallic acid, coumaric acid derivatives, ferulic acid, apigenin, proanthocyanidin B1, sinapic acid, hydroxybenzoic acid, coumaric acid, caffeoyl malic acid, caftaric acid, kaempferol, and glucosides of quercetin [10]. Many pharmacological studies have confirmed the antioxidant, antibacterial, anticancer, antipsoriatic, anti-inflammatory, cardioprotective [1], hepatoprotective [11], and antigenotoxicity [2] effects of WC.

\section{Methodology}

For this review article, the authors searched the literature utilizing three main search engines including PubMed (http://www.ncbi.nlm.nih.gov/pubmed), Google Scholar (http://scholar.google.com), and Science Direct (http:// www.sciencedirect.com). This review explores the antilipidemic, antidiabetic, antioxidant, antigenotoxic, hepatoprotective, renoprotective, anticancer, and antiinflammatory properties of $W C$ and its association with human diseases. The references included in this review contain 92 papers, comprising 85 original articles, 5 review articles, and 1 book and 1 congress abstract, dating from 1978 to May 2019. All full texts and abstracts of studies related to $W C$ have been taken, among which 2 documents have been written in Spanish and 1 document has been written in Persian, while the rest of the papers are in English. Unpublished congresses, communications, and thesis works have been excluded. The following key search terms were used ("Nasturtium officinale L." OR "N. officinale L." OR "Watercress") OR ("Nasturtium officinale" OR "Watercress" AND "anti-lipidemic" OR "anti-diabetic" OR "antioxidant" OR "anti-genotoxic" OR "hepatoprotective" OR "renoprotective" OR "anti-cancer" OR "anti-inflammatory"). The data taken was confirmed for their suitability and accuracy by the authors. The final data was prepared and has been discussed in the following sections.

\subsection{Phytochemical Characterization of Watercress.} Phytochemical characterizations of different parts of $W C$ were evaluated with a variety of methods (Figure 2). The high-performance liquid chromatography (HPLC) method showed two main types of metabolites in fresh baby-leaf of $W C$ which are phenolics and glucosinolates. As shown in Table 1, the main recognized phenolics were quercetin-3-O rutinoside, chlorogenic acid, isorhamnetin, and dicaffeoyltartaric acid, while the glucosinolates were made up of 2phenylethyl isothiocyanate (an antimicrobial compound) and gluconasturtiin (the precursor of the anticarcinogenic) [12].

Major phenolics that are found in extracts of $W C$ leaves were quercetin and kaempferol glycosides [13]. Another study showed that caffeoylmalic acid was the major phenolic composite in the WC extract; nevertheless, other components including ferulic acid, disinapoylgentibiose, and isorhamnetin-O-sophoroside-O-malonyl (hexoside) were detected as minor compounds [14]. Boligon et al. reported higher levels of hydroxycinnamic acids (chlorogenic and caffeic acids) than flavonoids (rutin) in WC extract [9]. On the contrary, Aires et al. determined isorhamnetin and rutin as major compounds in WC extracts [12]. 8-methylsulphinyloctyl isothiocyanate (MSO) and phenethyl isothiocyanates (PEITC) are two different isothiocyanates derivatives of $W C$ [15]. Rose et al. indicated that WC extract contains a high concentration of 


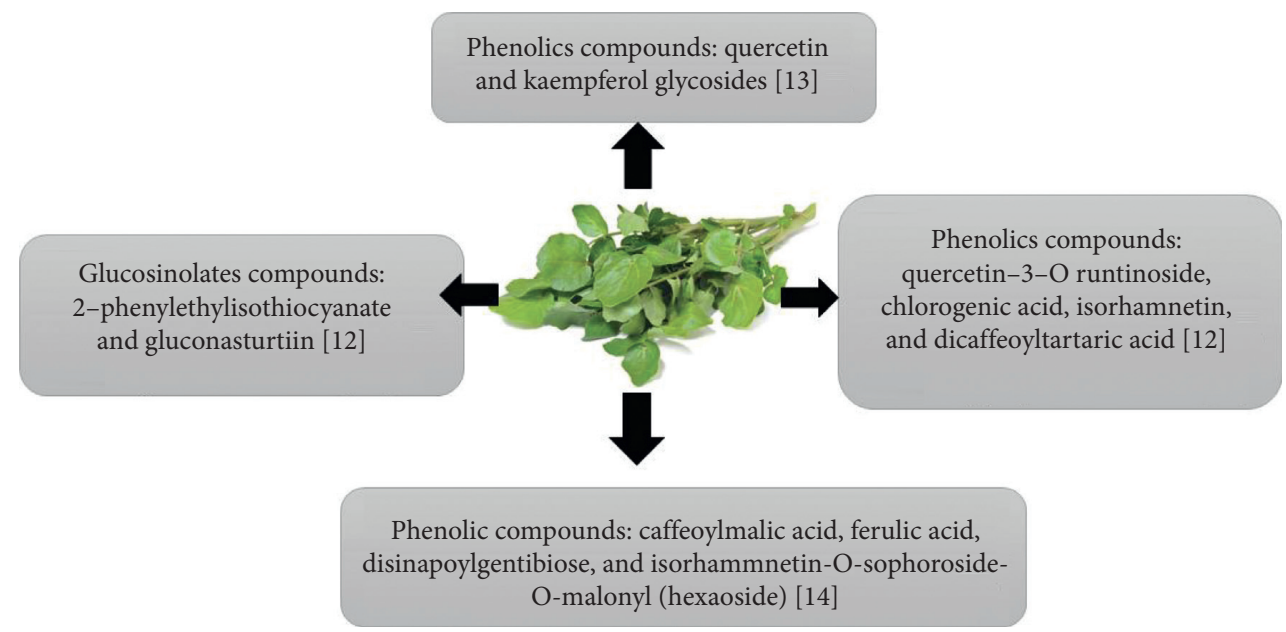

Figure 2: The main phytochemicals of Watercress extract.

TABLE 1: The main recognized metabolites in different parts of WC.

\begin{tabular}{lc}
\hline $\begin{array}{l}\text { Fresh baby-leaf of WC } \\
\text { Phenolics (quercetin-3-O rutinoside, chlorogenic acid, isorhamnetin, and dicaffeoyltartaric acid) [12] } \\
\text { Glucosinolates (2-phenylethyl isothiocyanate gluconasturtiin) }\end{array}$ \\
$\begin{array}{l}\text { Phenolics (quercetin and kaempferol glycosides) [13] caffeoylmalic acid [14] } \\
\text { Hydroxycinnamic acids (chlorogenic and caffeic acids) [9] } \\
\text { Isorhamnetin and rutin [12] }\end{array}$ \\
$\begin{array}{l}\text { Isothiocyanates (MSO and PEITC) [15] } \\
\text { Carotenoids (lutein and } \beta \text {-carotene) [16] }\end{array}$ \\
0047lucosinolates [17]
\end{tabular}

glucosinolates [17] and carotenoids such as lutein and $\beta$-carotene [16]. However, another study demonstrated that the aerial parts of $W C$ comprise the highest content of total phenolics compounds with an antioxidant activity which could be a valued natural antioxidant [19].

The main components in the oil of $W C$ flowers were limonene (43.6\%), p-cymene-8-ol (7.6\%), $\alpha$-terpinolene (19.7\%), and caryophyllene oxide (6.7\%). Caryophyllene oxide $(37.2 \%), \quad \alpha$-terpinolene $(15.2 \%), \quad$ p-cymene-8-ol (17.6\%), and limonene (11.8\%) were the central compounds in stems of $\mathrm{WC}$, while myristicin (57.6\%), $\alpha$-terpinolene $(8.9 \%)$, and limonene $(6.7 \%)$ were the main components in the oil of $W C$ leaves [5]. Zeb identified 20 components in the root of $W C$ such as the sinapic acid, coumaric acid, and its derivatives, quercetin derivatives, and caftaric acid which were the main phenolic components. Caftaric acid, coumaric acid, and its derivatives and quercetin derivatives were present abundantly in the leaves of WC among the 14 phenolic composites. Total phenolic compounds were higher in the methanolic extract of $W C$ rather than aqueous extract [18]. In another study, phytochemical analysis has discovered the presence of glucosinolates [20], phenolics, and flavonoids as principal compounds in WC extract [21].

Watercress contains some vitamins such as B, A, K, E, C, and $\mathrm{B}_{9}$, some ions/elements like calcium, magnesium, phosphor, potassium, iron, zinc, and sodium, and some substances like lutein, $\beta$-carotene, quercetin, and zeaxanthin [22]. Previous studies confirmed high antioxidant activities of $W C$ extracts $[9,13,14,18,19,23-28]$.

2.2. Effects of Watercress Extract on Lipid and Glucose Levels. Herbal medicines are commonly considered to have fewer side effects. They also are less toxic in comparison to synthetic agents. A resurgence of interest in this field resulted in the introduction of new therapeutic compounds including hypoglycemics and hypolipidemic agents [29]. Consuming WC extract can reduce the complications of hypercholesterolemia and hyperglycemia. Intragastric administration of WC (500 mg/kg BW per day for 10 and 30 days) to rats with hypercholesterolemia lowered their serum total cholesterol (TC) (by 34.2 and 37\%), triglycerides (TG) (by 30.1 and 44\%), and low-density lipoproteins cholesterol (LDL-C) (by 52.9 and $48 \%$ ) although it raised the serum high-density lipoproteins cholesterol (HDL-C) level (by 27 and 16\%) (Figure 3) $[29,30]$. The atherogenic index (AI, determined in terms of $\mathrm{LDL} / \mathrm{HDL}$ ratio) and the $\mathrm{HMG}$ CoA reductase activity showed a significant decrease in rats with hypercholesterolemia which were treated with $W C$ in comparison to rats with a high-fat diet [30]. Hadjzadeh et al. showed that 


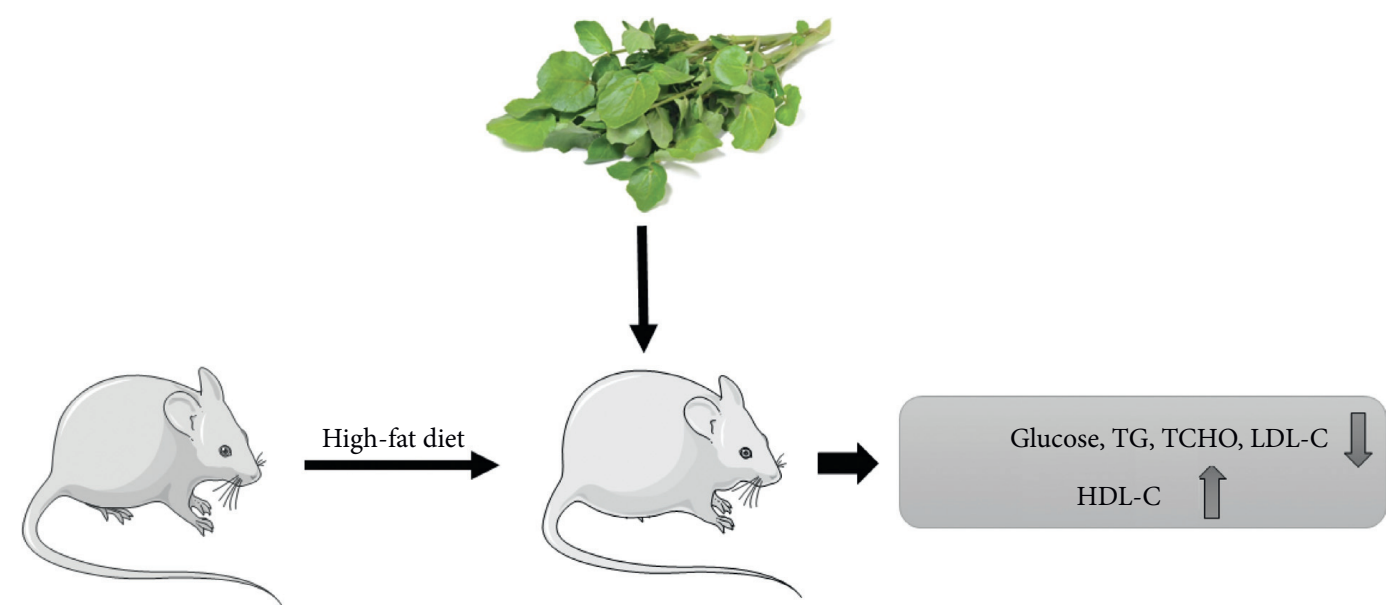

FIgURE 3: Effects of Watercress extract on lipid and glucose levels.

in four weeks, using a hydroalcoholic extract of $W C$ leaves $(200 \mathrm{mg} / \mathrm{kg})$ in treating diabetic rats could remarkably lower levels of TC and LDL-C in comparison to diabetic rats which left untreated but it had no effect on TG and HDL-C levels [31]. Another study observed that the ingestion of raw food (the mixture of 1 portion of $W C$ and 1 portion of black rice bran) for four weeks outstandingly lowered TC and TG levels and heightened HDL level but supplementation did not have a significant effect on LDL levels in the experimental animals with diabetes mellitus (DM) [22]. Contrastingly, Gill et al. showed that daily consumption of $85 \mathrm{~g}$ raw $W C$ for 8 weeks did not have any effect on the plasma lipid profile (TG, TC, HDL-C, and LDL-C) [21].

Hoseini et al. treated diabetic rats with diverse doses of the ethyl acetate (5 to $200 \mathrm{mg} / \mathrm{kg}$ ) methanol and aqueous extracts (10 to $1000 \mathrm{mg} / \mathrm{kg}$ ) of $W C$ for short-term (7 days) and long-term (56 days) studies with the use of gavage [32]. They observed that after one-week treatment with 800 and $1000 \mathrm{mg} / \mathrm{kg}$ of the methanolic extract of $W C$ and two months of treatment with $100 \mathrm{mg} / \mathrm{kg}$ of the ethyl extract blood glucose level remarkably decreased in comparison to untreated rats which were diabetic [32]. In line with these results, another study showed that the treatment of diabetic rats with hydroalcoholic extract of $W C(200 \mathrm{mg} / \mathrm{kg})$ leaves over four weeks outstandingly mitigated serum glucose in comparison to diabetic untreated rats [31]. Syamsinah and Anggraini demonstrated that a raw food (the mixture of 1 portion of $W C$ and 1 portion of black rice bran) for 4 weeks was able to lower the blood sugar content of the DM experimental animals [22]. Aqueous WC extract administration to hyperglycemic rats decreased glucose levels $(76.6 \%$ higher than insulin) and increased the number of $\beta$-cells in the pancreas of treated animals [33]. Fenton-Navarro et al. showed that the hypoglycemic effect of aqueous WC extract during acute mode was $76.6 \%$ more than that of insulin, and once aqueous $W C$ was used in the chronic period, the levels of glucose reached the normal range during the third week to the eighth week of the experiment. [34].

It seems that inhibition of carbohydrate digestive enzyme activity is an effective method of control for hyperglycemia in type 2 diabetes [35-37]. WC juice could restrain digestive enzymes in a dose-dependent manner, with a sturdier effect on $\alpha$-glucosidase rather than lipase and $\alpha$-amylase activity. $W C$ contains roseoside, pinoresinol, and glycosides, malic acid, and phenolic compounds [14]. The first three of them are $\alpha$-glucosidase inhibitory factors $[38,39]$, malic acid was recognized as the active agent for hindrance of $\alpha$-amylase, $\alpha$-glucosidase, and lipase in Flacourtia inermis Roxb fruits [35], and the last of them were also identified to interfere with pancreatic lipase activity [35-37]. Spínola et al. suggested that the preventing effects of WC juice against digestive enzymes may postpone carbohydrate and lipid hydrolysis in the digestive tract, which consecutively reduces the absorption of fatty acids and glucose [14].

The reduction of TG after the administration of $W C$ might be attributed to decreased TG absorption and higher excretion of TG via feces [40]. The decrease in the level of TC after receiving $W C$ may be due to increased excretion of bile acids, lower absorption of TC from the intestine, binding of $W C$ with bile acids in the intestine [41], reduction of cholesterol biosynthesis [42], and increasing receptors of LDL [31]. Furthermore, other studies suggested that the reduction of TC after treatment with $W C$ may be related to valued polyphenolic combinations such as total phenolics and flavonoids in this extract $[29,43]$.

The decrease in the level of glucose after administration of $W C$ extract may be due to its antioxidant properties and stimulating Langerhans islets, improving insulin secretion, and finally reducing blood glucose contents [31].

\subsection{Effects of Watercress Extract on Antioxidant System.} Administration of $W C$ extract in hypercholesterolaemic rats markedly augmented the superoxide dismutase (SOD) activity and catalase (CAT) activity and reduced glutathione (GSH) content in liver tissue while it significantly reduced hepatic glutathione reductase (GR) and glutathione peroxidase (GPx) activity as well as malondialdehyde (MDA) level [29]. Gill et al. showed that while the consumption of $85 \mathrm{~g}$ of raw $W C$ for 8 weeks along with their usual diet significantly increased plasma antioxidants (lutein and $\beta$ - 
carotene) in comparison to the control phase, the level of detoxifying enzymes (GPx and SOD) in erythrocytes and plasma total antioxidant status were not changed [21]. Hart showed that treatment with ethanolic extract of $W C$ (50-500 $\mathrm{mg}$ ) inhibited the lipid peroxidation process in different tissues such as the liver (88.78-97.41\%), brain (64.66-92.69\%), and kidney (71.80-97.06\%) [27]. Fogarty et al. showed that exercise-induced oxidative stress increased LPO, $\mathrm{H}_{2} \mathrm{O}_{2}$ accumulation, and lipid hydroperoxides (LOOH) while consumption of acute ( $2 \mathrm{~h}$ before exercise) and chronic (8 weeks) WC decreased LPO and $\mathrm{H}_{2} \mathrm{O}_{2}$ accumulation and $\mathrm{LOOH}$ formation. In addition, the levels of lipid-soluble antioxidants such as xanthophyll, $\gamma$-tocopherol, and $\alpha$-tocopherol markedly increased after consumption of $W C$ in acute and chronic groups [44]. Zargari et al. claimed that the administration of $W C$ extract in arsenic-induced oxidative damage markedly augmented the activities of antioxidant enzymes such as GPx and decreased MDA content in comparison to the normal group [45]. Cyclophosphamide- (CP-) induced oxidative effect increased LPO in RBC, SOD, and CAT activity in the bone marrow and liver tissue, SOD activity, and GSH to GSSG content in RBC while intake of WC in doses of 0.5 and $1 \mathrm{~g} / \mathrm{kg}$ BW for 15 days prior to $\mathrm{CP}$ administration reversed all parameters in comparison to relative control groups [46]. These findings are in line with other findings [29] where the treatment with $W C$ significantly reduced MDA content in hypercholesterolemic animals.

Bahramikia et al. showed that the addition of $\mathrm{Fe}^{2+}$ or ascorbic acid to the liver homogenate markedly augmented reactive oxygen species (ROS) production, protein carbonyl (PCO) formation (as a member of protein oxidation), lipid peroxidation (LPO), and loss of protein-bound sulphydryl (P-SH) groups while the $W C$ extract showed inhibitory activity compared to ROS and PCO formation as well as lipid and P-SH oxidation to different degrees [47]. In another study, treatment with $W C$ extract $(100$ and $200 \mathrm{mg} / \mathrm{kg}$ ) in gentamicin-induced rats not only significantly reduced ROS formation which was parallel to decrease in serum level of blood urea nitrogen, creatinine, pathological changes in kidney tissue, and LPO but also significantly inhibited the increased level of inflammation markers such as nitric oxide (NO) and tumor necrosis factor-alpha (TNF- $\alpha$ ) [8]. The derivatives of $W C$ juice including quercetin and phenethyl isothiocyanates (PEITC) have been shown to induce GST and CYP1A1 activities [48, 49]. Quercetin and PEITC increased transcription of GST and CYP1A1 by binding to xenobiotic responsive element and antioxidant responsive element region of the DNA $[50,51]$.

Keser et al. reported that lead $(\mathrm{Pb})$ poisoning led to the formation of lipid oxidation and activated antioxidant defense enzymes such as ascorbate peroxidase (APX), SOD, CAT, and GR in leaves of WC [6]. APX and CAT are metalloenzymes containing Fe. Srivastava et al. showed that treatment with arsenic decreased Fe concentration in plant tissues [52]. It can be concluded that decreasing activity of CAT and APX in roots of WC plants (at high arsenic concentration) is due to a shortage of Fe for the synthesis of these enzymes. Namdjoyan et al. suggested that treatment of
WC plants with nitric oxide molecule could indirectly or directly induce antioxidant enzymes to tolerate arsenicinduced damage [53] for the reason that NO has an antioxidant function and scavenges ROS that is produced in oxidative stress [54]. Rose et al. demonstrated that PEITC and MSO (the constituents of $W C$ ) reduced cyclooxygenase2 (COX-2) and inducible nitric oxide synthase (iNOS) protein expression levels [15]. In vitro exposure of peripheral blood mononuclear cell (PBMC) to WC or PEITC $(24 \mathrm{~h})$ augmented the gene expression of GPx and SOD. Additionally, $W C$ extract increased SOD activity nearly twofold, while PEITC had no effect [55]. This potential may be due to auxiliary bioactive components in $W C$ extract such as hydroxycinnamic acids or quercetin glycosides [56].

The strong antioxidant activity of ethanolic extracts of $W C$ has been confirmed by diverse mechanisms including binding to transition metal ions, inhibition of chain beginning, removal of peroxides, scavenging of free radicals, and prevention of continual hydrogen abstraction [27, 57]. Lhoste showed that WC could activate phase I and phase II detoxification enzymes' activities and inhibited genotoxicity in HepG2 cells [58]. According to the high total of flavonoids and phenolics of WC extract, it has the potential for inhibition of LPO, enhancement of antioxidant capacity, and restoration of GSH content in the animal model with a highfat diet [29]. There is a phenolic hydroxyl group in polyphenols that competitively reacts with ROS and reduces LPO. Moreover, flavonoid or phenolic compounds of $W C$ extract have adequate ability to scavenge NO molecule. Bahramikia et al. observed that the various antioxidant properties of WC may be related to direct trapping of ROS, reductive capacity, metal chelating ability, and LPO inhibition [26].

A high concentration of lipid-soluble antioxidants and cellular exposure to constituents of $W C$ (such as isothiocyanates) may indicate a probable mechanism for the reduction of LOOH. It is plausible that the elevated lipidsoluble antioxidants can directly scavenge superoxide radicals and lead to a reduction of $\mathrm{H}_{2} \mathrm{O}_{2}$ formation. Gill et al. showed that $W C$ can elevate aqueous and lipid-soluble antioxidants in healthy adults as follows: $\beta$-carotene $(33 \%)$, ascorbic acid (35\%), and $\alpha$-tocopherol (26\%) [21]. Forgarty et al. showed that the lipid-soluble antioxidants including $\gamma$-tocopherol, $\alpha$-tocopherol, and xanthophyll augmented after consumption of WC [44].

Akbari Bazm et al. investigated the effect of $W C$ on oxymetholone-induced oxidative injury in mouse testis. They showed that $W C$ extract at 50 and $100 \mathrm{mg} / \mathrm{kg}$ dosages meaningfully increased the testis tissue FRAP levels and at a dosage of $100 \mathrm{mg} / \mathrm{kg}$ significantly diminished the serum levels of NO. They concluded that WC extract has protective effects against testicular toxicity caused by oxymetholone [59]. Our study showed that WC extract $(500 \mathrm{mg} / \mathrm{kg})$ significantly augmented GPx activity and T-SH level in comparison to acetaminophen- (APAP-) treated rats [11]. In addition, our group reported that WC extract markedly increased GPx enzyme activity and significantly diminished hydroxyproline and PCO levels in the liver tissue of bile duct ligated (BDL) rats [60]. 
2.4. Effects of Watercress Extract on DNA Damage. DNA damage has a vital role in cancer, mutagenesis, aging, and other disorders. Consumption of food that is rich in polyphenols such as $W C$ extract is a good strategy in reducing oxidative stress and DNA damage (Figure 4) [61]. WC extract did not activate cytotoxicity, chromosomal instability, and clastogenicity [62]. In addition, $W C$ extract had no role in genetic damage [61] and is not genotoxic in vivo [63].

Casanova et al. showed that aqueous extract of $W C$ had an antigenotoxic effect against $\mathrm{H}_{2} \mathrm{O}_{2}$-induced DNA damage [62]. Fogarty et al. showed that exercise-induced oxidative stress increased DNA damage, while consumption of $W C$ at acute ( $2 \mathrm{~h}$ before exercise) and chronic ( 8 weeks) phases attenuated DNA damage [44]. Another study showed that intake of $85 \mathrm{~g}$ raw $W C$ for 8 weeks daily significantly reduced DNA damage in lymphocytes [21]. Zargari et al. indicated that arsenic-induced oxidative stress increased DNA damage, whereas WC consumption significantly decreased 8hydroxydeoxyguanosine (one of the major products of DNA oxidation) level in liver tissue [45]. Boyd et al. showed that treatment with $50 \mu \mathrm{l} / \mathrm{ml}$ of $W C$ extract significantly reduced $\mathrm{H}_{2} \mathrm{O}_{2}$-induced DNA damage in HT29 cells [56]. Another study showed that the $W C$ extract exerted antigenotoxic activity against oxidative damage after 4 hours of incubation [64]. In addition, a WC-supplemented diet demonstrated a protecting effect against in vivo DNA damage induced by CP [63].

A high concentration of lipid-soluble antioxidants and cellular exposure to components of $W C$ (antioxidants and isothiocyanates) may show a potential mechanism for the stabilization of cell DNA [21]. Another study suggested that the antimutagenic effect of $W C$ may be related to the antioxidant capability of the extract because leaves of $W C$ were proved to have a high content of polyphenols, carotenoids, glucosinolates, and chlorophyll [62]. Hofmann et al. observed that in vitro and in vivo blood cells respond with bioactive materials in WC by upregulation of GPX and SOD expression which may be a reason for reducing DNA damage following $W C$ consumption $[21,55,56]$.

PEITC was found to be genotoxic [50] and was not seen in the crude $W C$ extract [56]. However, the antigenotoxic effects could not be attributed to PEITC content [56] and may be related to quercetin and hydroxycinnamic acid (HCA) derivatives that were detected in the crude $W C$ extract $[65,66]$. The antigenotoxic activity of $W C$ may be related to the antioxidant ability [64]. Aksornthong et al. showed that heat could deactivate plant myrosinase and could reduce the antitumor activity of fresh WC [67]. Another study found that PEITC and WC extract independently control cellular metabolism and cooperatively improve the therapeutic effects of radiotherapy [7].

2.5. Effects of Watercress Extract on Hepatotoxicity. There was no significant change in the activity of aminotransferase enzymes (AST and ALT) in animals treated with the total extract of $W C$ or three fractions at the dose of $175 \mathrm{mg} / \mathrm{kg}$ in comparison to control rats. Acetaminophen caused significant hepatocellular damage and elevated serum levels of AST, ALT, and LDH $(p<0.001)$, while treatment with the total extract of $W C(175 \mathrm{mg} / \mathrm{kg})$ and aqueous fraction $(50 \mathrm{mg} / \mathrm{kg}$ ) significantly decreased these markers. The LD50 value of the petroleum extract was more than $3823 \mathrm{mg} / \mathrm{kg}$, while the other two fractions and total extract of $W C$ were nontoxic up to $5734 \mathrm{mg} / \mathrm{kg}$. Acetaminophen-induced histopathological changes of the liver were noticeably reversed after treatment by an aqueous fraction and total extract of WC [68]. Zargari et al. indicated that WC consumption significantly increased the activities of SOD, CAT, and GPx, while it lowered MDA and 8-hydroxydeoxyguanosine (8OHdG) levels in the liver. They concluded that $W C$ reduced oxidative damage induced by arsenic in the liver [45]. Ebadollahi Natanzi et al. evaluated hepatoprotective effects of $W C$ by using a rat liver perfusion system. Adult male rats were selected for investigating the hepatoprotective effect of $W C$ against acetaminophen toxicity. Alcoholic extract of WC significantly lowered the increased activity of both AST and ALT enzymes induced by acetaminophen [69]. Karami et al. examined the hepatoprotective activity of the methanolic fraction of $W C$ against gamma radiation-induced hepatotoxicity. They showed that after a pretreatment step with $100 \mathrm{mg} / \mathrm{kg} \mathrm{BW}$ for 15 days consecutively and $2 \mathrm{~h}$ before $\gamma$-radiation, the frequency of inflammation was significantly lowered. Moreover, a slight decrease in liver cell necrosis, edema, and congestion was observed. The existence of isothiocyanates and phenols in the methanolic fraction of $W C$ which acted as antioxidant agents may be an explanation for this protective activity [70]. Recently, in our study, we investigated the hepatoprotective effect of $W C$ extract in APAP-induced hepatotoxicity. We showed that administration of WC extract $(500 \mathrm{mg} / \mathrm{kg})$ caused a marked decrease in AST activity in comparison to APAP treated rats [11]. Sadeghi et al. indicated that $W C$ extract reduced liver damage in BDL animals by decreasing the histopathological indices and hydroxyproline level. They recommended that this extract may be a new therapeutic agent for cholestatic hepatic damage [60].

2.6. Anticancer Effects of Watercress Extract. Watercress has antitumor activity since it can interfere with several axes including oxidative stress, apoptosis, cell cycle progression, and MAPK. [21, 71]. Several studies proposed that diets rich in cruciferous vegetable $(\mathrm{CV})$ plants can reduce the risk of lung cancer, colorectal carcinoma, and prostate cancer [72-75]. CVs are rich in glucosinolates and this compound altered to isothiocyanates (ITCs) in the human intestinal microflora or plants [72]. ITCs are characterized as a type of chemopreventive factor which may have a key role in the control of carcinogenesis. It has been shown that ITCs have strong tumor protective effects in experimental models $[6,76]$. Morse et al. showed that dietary ITCs prevent the growth of lung tumors in the animal model induced by tobacco-derived carcinogens [77].

Several studies have explored the potential anticancer effects of $W C$ extract, most of which mainly focused on its chemopreventive abilities. Boyd and his colleagues proved 


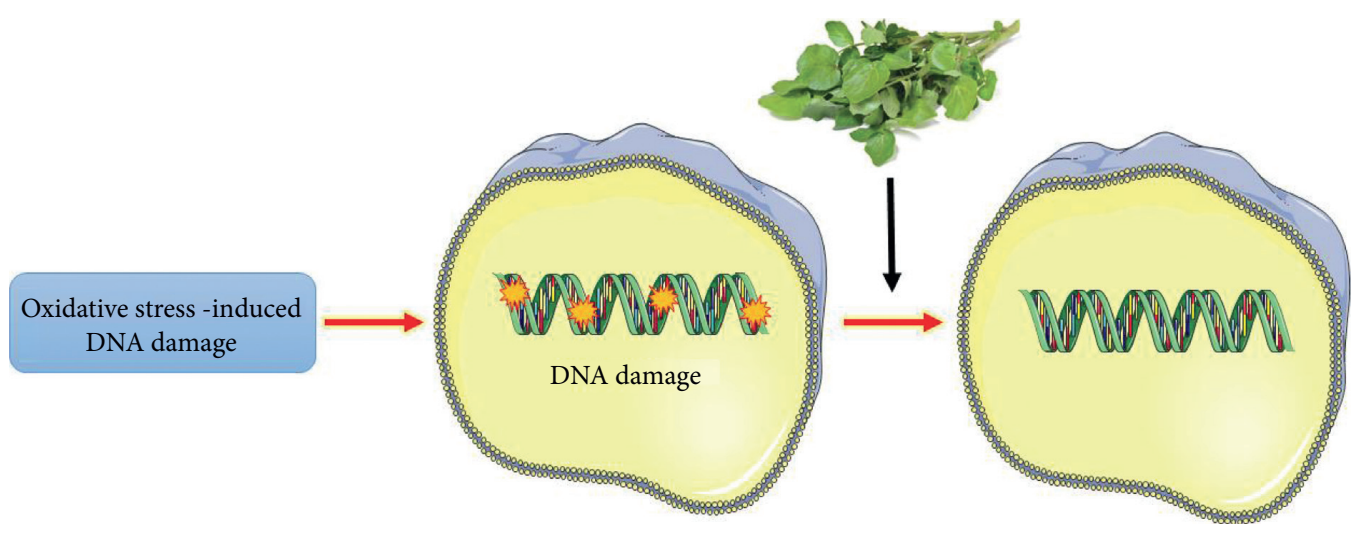

FIgURE 4: Effects of Watercress extract on DNA damage.

that DNA injury induced by $\mathrm{H}_{2} \mathrm{O}_{2}, 4$-Hydroxy Nonenal (4HNE), and fecal water was prevented in colon cancer HT29 cell line when treated by $W C$ extract. Moreover, the addition of $W C$ extract to hepatic cell line hepg2 has been shown to protect against DNA damage induced by benzo(a) pyrene [56]. Rose et al. revealed that adding $0.5 \mu \mathrm{M}$ of 8 methylthiooctyl-ITC and $0.2 \mu \mathrm{M}$ of 7 -methylthioheptyl-ITC increased quinone reductase (QR) twofold activity while $5 \mu \mathrm{M}$ of PEITC was required to achieve the same outcomes. It has been shown that glutathione conjugation of PEITC and S-(N- $\beta$-phenylethylthiocarbomyl) glutathione (PECG) have the same potency as PEITC in increasing QR activity [17]. Human studies also indicated these chemopreventive capabilities. Hecht et al. stated that stimulation of 4-(methylnitrosamino)-1-(3-pyridyl-1-butanone (NNK), which is an important tobacco carcinogen in smoker participants, was inhibited by the consumption of $56.8 \mathrm{~g}$ $W C$ for 3 days [78].

Some researchers started to explore the antimetastatic and antiproliferation effect of $W C[56,79]$. Boyd et al. proved that $W C$ extract inhibited the cell cycle progression of HT29 cells and human colon adenocarcinoma cell line. It also inhibited the invasion of the HT115 cell line through matrigel (11). Rose et al. demonstrated that treatment with 7methylsulphinylheptyl isothiocyanate (a component of WC) reduced MMP9 activity in the MDA-MB-231 (human breast cancer cell line). MMP9 is an enzyme with a proteolytic activity that is crucial for cell invasion and usually augmented in cancer cells. Because of the instability of the other ITCs existing in WC, Rose et al. did not test them in this investigation but they evaluated broccoli extract and demonstrated that 4-methylsulphinylbutyl (sulforaphane) components of extract had similar anti-invasive and antimetalloproteinase activity to methylsulfinylheptyl-ITC in $W C$ indicating that this effect is not limited to specific ITCs [79]. Souza et al. explored the effects of aqueous extract of $W C$ on the growth of the Ehrlich tumor. They showed that the animals in the treatment group showed suppression of tumor growth and a small area of necrosis [80]. Moradi and colleagues revealed that with an increase in the concentration of WC extract, the survival rate of the cancerous Hela cells was reduced. They concluded that hydroalcoholic fraction of WC can prevent the growth of Hela cells and may be considered as an alternative cure for cervical cancer [81].

As mentioned above, $W C$ contains abundant amounts of carotenoids such as beta-carotene and lutein. It has been demonstrated that carotenoids are correlated with antitumor activity [82]. Lutein is a powerful antioxidant that inhibits tissue injury and is associated with a decreased risk of colon cancer [83]. Beta-carotene consumed in physiological contents in combination with antioxidant components may have an anticancer effect in healthy populations $[84,85]$.

2.7. Effects of Watercress Extract on Nephrotoxicity. Shahani et al. examined the protective effect of hydroalcoholic extract of $W C$ against mitochondrial dysfunction induced by gentamicin (GM) in mitochondria of rat's kidney. They showed that administration of GM led to a significant decrease in mitochondrial function and glutathione content in mitochondria isolated from the kidney. They applied hydroalcoholic extract of $W C$ to rats treated with GM. They reported that this extract significantly lowered mitochondrial function and glutathione content in the kidney-isolated mitochondria. In comparison to the control group, WC extract significantly lowered glutathione oxidation, MDA, and mitochondrial swelling in a dosedependent manner [86]. Shahani and colleagues in another study showed that administration of WC extract (100 and $200 \mathrm{mg} / \mathrm{kg}$ ) significantly reduced the ROS formation and serum level of blood urea nitrogen, and creatinine modulated the pathological changes in kidney tissue. It also inhibited the elevated level of inflammation markers such as TNF- $\alpha$ and NO in GM-induced nephrotoxicity [8]. Mehrabi et al. revealed that there were no substantial effects of $W C$ extract administration in urinary and chemical parameters in calcium oxalate crystal formation. However, an extract with a low dosage had some suppressive effects on the formation of kidney stones induced by ethylene glycol in rats [87]. Traditionally, native inhabitants of the Zagros Mountains used the aerial parts of the $W C$ for the alleviation of rheumatic pain, abdominal pain, and urinary stones. Furthermore, new studies showed the analgesic activity of 
TABLE 2: The clinical trials and cell line studies for watercress.

A single-blind,

Gill CI et al. randomized, crossover $85 \mathrm{~g}$ raw watercress daily for 8 week study

\begin{tabular}{|c|c|c|c|}
\hline $\begin{array}{l}\text { Fogarty } \\
\text { et al. }\end{array}$ & $\begin{array}{l}\text { Randomized controlled } \\
\text { investigation }\end{array}$ & $\begin{array}{l}\text { Acute (consumption } 2 \mathrm{~h} \text { before } \\
\text { exercise) and chronic ( } 8 \text { weeks } \\
\text { consumption) }\end{array}$ & $\begin{array}{c}\text { Acute and chronic WC supplementation attenuates } \\
\text { exercise-induced peripheral mononuclear cell DNA } \\
\text { damage and lipid peroxidation [44] }\end{array}$ \\
\hline $\begin{array}{l}\text { Hofmann } \\
\text { et al. }\end{array}$ & - & $85 \mathrm{~g}$ WC per day for 8 weeks & $\begin{array}{l}\text { WC modulated the enzymes SOD and GPX in blood cells in } \\
\text { vitro and in vivo [55] }\end{array}$ \\
\hline Boyd et al. & $\begin{array}{l}\text { Human colon cancer } \\
\text { cells (HT29) }\end{array}$ & - & $\begin{array}{l}\text { WC extract protective against the three stages of the } \\
\text { carcinogenesis process }[56]\end{array}$ \\
\hline Lhoste et al. & Human HepG2 cells & - & $\begin{array}{c}\text { WC acted as a bifunctional inducer by enhancing both } \\
\text { phase I and phase II enzymes [58] }\end{array}$ \\
\hline Hecht et al. & - & $\begin{array}{c}2 \text { ounces }(56.8 \mathrm{~g}) \text { of watercress at } \\
\text { each meal for } 3 \text { days }\end{array}$ & $\begin{array}{l}\text { Effects of watercress consumption on metabolism of a } \\
\text { tobacco-specific lung carcinogen in smokers [78] }\end{array}$ \\
\hline Rose et al. & $\begin{array}{l}\text { Human MDA-MB-231 } \\
\text { breast cancer cells }\end{array}$ & - & $\begin{array}{l}\text { WC suppressed matrix metalloproteinase- } 9 \text { activity and } \\
\text { invasiveness of human MDA-MB-231 breast cancer cells } \\
{[79]}\end{array}$ \\
\hline
\end{tabular}

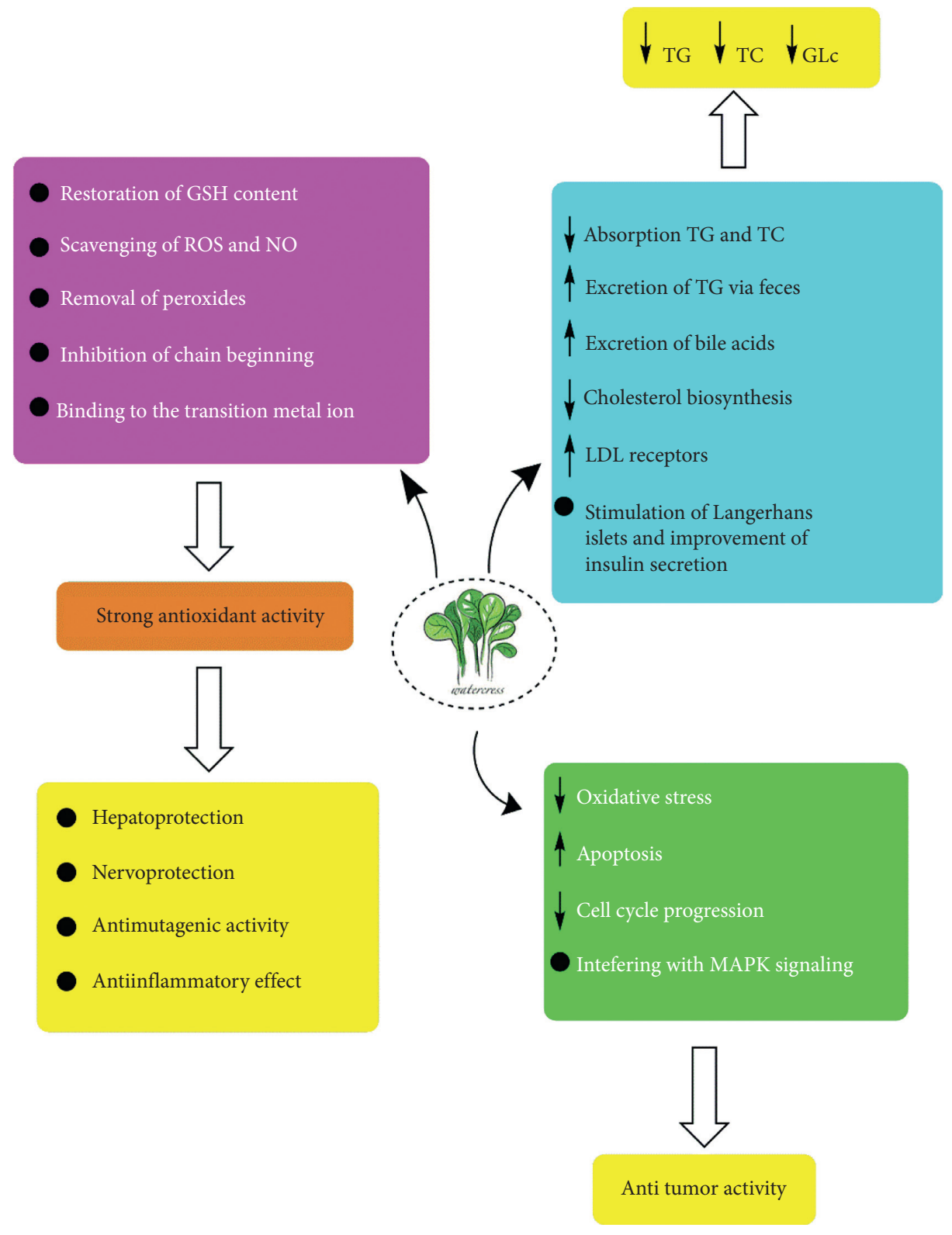

FIGURE 5: The suggested mechanisms for therapeutic potentials of watercress in human disorders. 
$W C[88,89]$. Zarfari et al. indicated that WC extract significantly increased the activity of antioxidant enzymes and total antioxidant capacity, reduced MDA and uric acid levels, and consequently led to a reduction of arsenite-induced renal toxicity [45]. Karami et al. revealed that vancomycin-induced nephrotoxicity increased serum uric acid, creatinine, and MDA in blood and kidney. They showed that after administration of $W C$ extract $(500 \mathrm{mg} / \mathrm{kg}), \mathrm{MDA}$, creatinine, and uric acid levels in serum were significantly reduced [90].

2.8. Anti-Inflammatory Effects of Watercress Extract. MSO and PEITC are two phytochemical components that are present in the $W C$ extract. In vitro study showed that nitrite and prostaglandin E2 synthesis was reduced by ITCs and MSO in Raw 264.7 cells that lower the secretion of proinflammatory mediators. Interestingly, both MSO and PEITC reduce COX-2 and iNOS protein expression by deactivation of nuclear factor$\kappa \mathrm{B}$ and stabilization of $\mathrm{I} \kappa \mathrm{B} \alpha[15]$. Sadeghi et al. investigated the anti-inflammatory activity of $W C$ in the topical and systemic form and recommended this extract as an anti-inflammatory factor [91]. Furthermore, Shahani et al. indicated that treatment with extract of $W C(50,100$, and $200 \mathrm{mg} / \mathrm{kg} \mathrm{BW})$ significantly reduced TNF- $\alpha$ and NO in GM-induced nephrotoxicity [8]. Camponogara et al. evaluated the anti-inflammatory effect of $W C$ extract on skin inflammation induced by croton oil in mice. They observed that $W C$ extract and $W C$ gel inhibited the ear edema and decreased the inflammatory cells infiltration for the acute and chronic model. It also decreased the levels of the proinflammatory cytokines (for acute model). This study demonstrated that WC may be a favorable topical, anti-inflammatory compound for treating inflammatory diseases [92].

\section{Conclusion}

Table 2 shows the clinical trials and cell line studies for the watercress. In traditional medicine, $W C$ is a known remedy for hypercholesterolemia, hyperglycemia, hypertension, arthritis, bronchitis, diuresis, odontalgia, and scurvy. It also acts as an antiestrogenic and can be used as a nutritional supplement. It has been reported that these therapeutic effects are due to primary metabolites such as isothiocyanates, glucosinolates, polyphenols (flavonoids, phenolic acids, and proanthocyanidins), vitamins $\left(\mathrm{B}_{1}, \mathrm{~B}_{2}, \mathrm{~B}_{3}, \mathrm{~B}_{6}, \mathrm{E}\right.$, and $\left.\mathrm{C}\right)$, terpenes (including carotenoids), and bioelements which exist in this plant. As shown in Figure 5, the reduction of TG, TC, and glucose after the administration of $W C$ might be related to decreased absorption TG and TC, higher excretion of TG via feces, higher excretion of bile acids, reduction of cholesterol biosynthesis, an increase in the numbers of LDL receptors, stimulation of Langerhans islets, and improvement of insulin secretion. The strong antioxidant activity of WC extract has been confirmed by diverse mechanisms including binding to the transition metal ion, inhibition of chain beginning, removal of peroxides, scavenging of ROS and NO, and restoration of GSH content. The antimutagenic effect of WC may be related to the antioxidant capability of the extract because the leaves of $W C$ comprise high content of polyphenols, carotenoids, glucosinolates, and chlorophyll. It has been proved that carotenoids have antitumor activities. Lutein is a powerful antioxidant that inhibits tissue damage and can lower the risk of colon cancer. WC has antitumor activity by interfering with several pathways including oxidative stress, apoptosis, cell cycle progression, and MAPK signaling. Furthermore, the anti-inflammatory, hepatoprotective, and renoprotective effects of $W C$ extract confirmed that these abilities are related to its antioxidant capacity. Currently, $W C$ is the object of numerous pharmacological studies that have demonstrated its antioxidant, anticancer, anti-inflammatory, antipsoriatic, renoprotective, hepatoprotective, and antigenotoxic effects.

\section{Abbreviations}

WC: Watercress

HPLC: High-performance liquid chromatography

MSO: 8-methylsulphinyloctyl isothiocyanate

TC: $\quad$ Total cholesterol

TG: $\quad$ Triglycerides

LDL-C: Low-density lipoproteins cholesterol

HDL-C: High-density lipoproteins cholesterol

DM: $\quad$ Diabetes mellitus

SOD: $\quad$ Superoxide dismutase

CAT: Catalase

GSH: Reduced glutathione

GR: Glutathione reductase

GPx: $\quad$ Glutathione peroxidase

MDA: Malondialdehyde

LOOH: Lipid hydroperoxides

CP: Cyclophosphamide

ROS: $\quad$ Reactive oxygen species

PCO: Protein carbonyl

LPO: Lipid peroxidation

P-SH: Protein-bound sulphydryl

NO: $\quad$ Nitric oxide

TNF- $\alpha$ : Tumor necrosis factor-alpha

PEITC: Phenethyl isothiocyanates

APX: Ascorbate peroxidase

COX-2: Cyclooxygenase-2

iNOS: Inducible nitric oxide synthase

PBMC: $\quad$ Peripheral blood mononuclear cell

BDL: $\quad$ Bile duct ligated

HCAs: Hydroxycinnamic acids

8-OHdG: 8-Hydroxydeoxyguanosine

CV: $\quad$ Cruciferous vegetables

4-HNE: 4-Hydroxy Nonenal

PECG: $\quad$ S-(N- $\beta$-phenylethylthiocarbomyl) glutathione

GM: $\quad$ Gentamicin.

\section{Data Availability}

The data supporting the findings of this study are included within the article.

\section{Conflicts of Interest}

The authors declare that they have no conflicts of interest. 


\section{Acknowledgments}

The authors thank the Vice-Chancellor for the research of Yasuj University of Medical Sciences for supporting this work.

\section{References}

[1] M. Klimek-Szczykutowicz, A. Szopa, and H. Ekiert, "Chemical composition, traditional and professional use in medicine, application in environmental protection, position in food and cosmetics industries, and biotechnological studies of Nasturtium officinale (watercress) - a review," Fitoterapia, vol. 129, pp. 283-292, 2018.

[2] M. Sakil, M. Polash, S. Afrin, and M. Hossain, "Evaluation of morphological traits, phytochemical compositions and antioxidant properties of watercress leaves," Progressive Agriculture, vol. 30, pp. 10-16, 2019.

[3] T. Ozen, "Investigation of antioxidant properties of Nasturtium officinale (watercress) leaf extracts," Acta Poloniae Pharmaceutica, vol. 66, no. 2, pp. 187-193, 2009.

[4] Z. R. Mousa-Al-Reza Hadjzadeh, R. Moradi, and A. Ghorbani, "Effects of hydroalcoholic extract of watercress (Nasturtium officinale) leaves on serum glucose and lipid levels in diabetic rats," Indian Journal of Physiology and Pharmacology, vol. 59, pp. 223-230, 2015.

[5] H. Amiri, "Volatile constituents and antioxidant activity of flowers, stems and leaves of Nasturtium officinale R. Br," Natural Product Research, vol. 26, no. 2, pp. 109-115, 2012.

[6] G. Keser and S. Saygideger, "Effects of lead on the activities of antioxidant enzymes in watercress, nasturtium officinale R. Br," Biological Trace Element Research, vol. 137, no. 2, pp. 235-243, 2010.

[7] N. S. Giallourou, I. R. Rowland, S. D. Rothwell, G. Packham, D. M. Commane, and J. R. Swann, "Metabolic targets of watercress and PEITC in MCF-7 and MCF-10A cells explain differential sensitisation responses to ionising radiation," European Journal of Nutrition, vol. 58, pp. 1-15, 2018.

[8] S. Shahani, F. Behzadfar, D. Jahani, M. Ghasemi, and F. Shaki, "Antioxidant and anti-inflammatory effects of Nasturtium officinale involved in attenuation of gentamicin-induced nephrotoxicity," Toxicology Mechanisms and Methods, vol. 27, no. 2, pp. 107-114, 2017.

[9] A. A. Boligon, V. Janovik, A. A. Boligon et al., "HPLC analysis of polyphenolic compounds and antioxidant activity inNasturtium officinale," International Journal of Food Properties, vol. 16, no. 1, pp. 61-69, 2013.

[10] A. Zeb and A. Habib, "Lipid oxidation and changes in the phenolic profile of watercress (Nasturtium officinale L.) leaves during frying," Journal of Food Measurement and Characterization, vol. 12, no. 4, pp. 2677-2684, 2018.

[11] N. Azarmehr, P. Afshar, M. Moradi et al., "Hepatoprotective and antioxidant activity of watercress extract on acetaminophen-induced hepatotoxicity in rats," Heliyon, vol. 5, no. 7, Article ID e02072, 2019.

[12] A. Aires, R. Carvalho, E. A. S. Rosa, and M. J. Saavedra, "Phytochemical characterization and antioxidant properties of baby-leaf watercress produced under organic production system," CyTA-Journal of Food, vol. 11, no. 4, pp. 343-351, 2013.

[13] R. Llorach, A. Martínez-Sánchez, F. A. Tomás-Barberán, M. I. Gil, and F. Ferreres, "Characterisation of polyphenols and antioxidant properties of five lettuce varieties and escarole," Food Chemistry, vol. 108, no. 3, pp. 1028-1038, 2008.
[14] V. Spínola, J. Pinto, and P. C. Castilho, "In vitro studies on the effect of watercress juice on digestive enzymes relevant to type 2 diabetes and obesity and antioxidant activity," Journal of Food Biochemistry, vol. 41, no. 1, 2017.

[15] P. Rose, Y. K. Won, C. N. Ong, and M. Whiteman, " $\beta$-Phenylethyl and 8-methylsulphinyloctyl isothiocyanates, constituents of watercress, suppress LPS induced production of nitric oxide and prostaglandin E2 in RAW 264.7 macrophages," Nitric Oxide, vol. 12, no. 4, pp. 237-243, 2005.

[16] M. E. O'neill, Y. Carroll, B. Corridan et al., "A European carotenoid database to assess carotenoid intakes and its use in a five-country comparative study," British Journal of Nutrition, vol. 85, no. 4, pp. 499-507, 2001.

[17] P. Rose, K. Faulkner, G. Williamson, and R. Mithen, "7Methylsulfinylheptyl and 8-methylsulfinyloctyl isothiocyanates from watercress are potent inducers of phase II enzymes," Carcinogenesis, vol. 21, no. 11, pp. 1983-1988, 2000.

[18] A. Zeb, "Phenolic profile and antioxidant potential of wild watercress (Nasturtium officinale L.)," SpringerPlus, vol. 4, no. 1, p. 714, 2015.

[19] M. Mazandarani, A. Momeji, and M. P. Zarghami, "Evaluation of phytochemical and antioxidant activities from different parts of Nasturtium officinale R. Br. in Mazandaran," Plant Physiology.vol. 3, no. 2, pp. 659-664, 2012.

[20] G. Engelen-Eigles, G. Holden, J. D. Cohen, and G. Gardner, "The effect of temperature, photoperiod, and light quality on gluconasturtiin concentration in watercress (nasturtium officinale R. Br.)," Journal of Agricultural and Food Chemistry, vol. 54, no. 2, pp. 328-334, 2006.

[21] C. I. Gill, S. Haldar, L. A. Boyd et al., "Watercress supplementation in diet reduces lymphocyte DNA damage and alters blood antioxidant status in healthy adults," The American Journal of Clinical Nutrition, vol. 85, no. 2, pp. 504-510, 2007.

[22] A. Syamsianah and H. Anggraini, Control of Lipid Profile on Diabetes Mellitus Animal Models with Watercress and Black Rice Bran, Prosiding seminar nasional \& internasional, Semarang, Indonesia, 2016.

[23] M. Isabelle, B. L. Lee, M. T. Lim, W.-P. Koh, D. Huang, and C. N. Ong, "Antioxidant activity and profiles of common vegetables in Singapore," Food Chemistry, vol. 120, no. 4, pp. 993-1003, 2010.

[24] A. P. Tiveron, P. S. Melo, K. B. Bergamaschi, T. M. F. S. Vieira, M. A. B. Regitano-d'Arce, and S. M. Alencar, "Antioxidant activity of Brazilian vegetables and its relation with phenolic composition," International Journal of Molecular Sciences, vol. 13, no. 7, pp. 8943-8957, 2012.

[25] A. C. Payne, A. Mazzer, G. J. J. Clarkson, and G. Taylor, "Antioxidant assays-consistent findings from FRAP and ORAC reveal a negative impact of organic cultivation on antioxidant potential in spinach but not watercress or rocket leaves," Food Science \& Nutrition, vol. 1, no. 6, pp. 439-444, 2013.

[26] S. Bahramikia and R. Yazdanparast, "Antioxidant efficacy of Nasturtium officinale extracts using various in vitro assay systems," Journal of Acupuncture and Meridian Studies, vol. 3, no. 4, pp. 283-290, 2010.

[27] T. Ozen, "Investigation of antioxidant properties of Nasturtium officinale (watercress) leaf extracts," Acta Poloniae Pharmaceutica, vol. 66, no. 2, pp. 187-193, 2008.

[28] D. J. Hart and K. J. Scott, "Development and evaluation of an HPLC method for the analysis of carotenoids in foods, and the measurement of the carotenoid content of vegetables and 
fruits commonly consumed in the UK," Food Chemistry, vol. 54, no. 1, pp. 101-111, 1995.

[29] R. Yazdanparast, S. Bahramikia, and A. Ardestani, "Nasturtium officinale reduces oxidative stress and enhances antioxidant capacity in hypercholesterolaemic rats," ChemicoBiological Interactions, vol. 172, no. 3, pp. 176-184, 2008.

[30] S. Bahramikia and R. Yazdanparast, "Effect of hydroalcoholic extracts of Nasturtium officinale leaves on lipid profile in high-fat diet rats," Journal of Ethnopharmacology, vol. 115, no. 1, pp. 116-121, 2008.

[31] M.-A.-R. Hadjzadeh, Z. Rajaei, R. Moradi, and A. Ghorbani, "Effects of hydroalcoholic extract of watercress (Nasturtium officinale) leaves on serum glucose and lipid levels in diabetic rats," Indian Journal of Physiology and Pharmacology, vol. 59, 2015.

[32] H. F. Hoseini, A. R. Gohari, S. Saeidnia, N. S. Majd, and A. Hadjiakhoondi, "The effect of Nasturtium officinale on blood glucose level in diabetic rats," Pharmacologyonline, vol. 3, pp. 866-871, 2009.

[33] B. Fenton-Navarro, M. Urquiza-Martinez, B. Fiscal-Castro, B. Nateras-Marín, M. López-Rodríguez, and A. VázquezHernández, "Evaluation of the hypoglycemic and oxidative stress effect of watercress (Nasturtium officinale) on hyperglycemic rats," Planta Medica, vol. 81, pp. S1-S381, 2016.

[34] B. Fenton-Navarro, M. U. Martínez, B. F. Castro et al., "Antioxidant and hypoglycemic effects of watercress (Nasturtium officinale) extracts in diabetic rats," African Journal of Traditional, Complementary and Alternative Medicines, vol. 15, no. 2, pp. 68-79, 2018.

[35] A. G. A. W. Alakolanga, N. S. Kumar, L. Jayasinghe, and Y. Fujimoto, "Antioxidant property and $\alpha$-glucosidase, $\alpha$-amylase and lipase inhibiting activities of Flacourtia inermis fruits: characterization of malic acid as an inhibitor of the enzymes," Journal of Food Science and Technology, vol. 52, no. 12, pp. 8383-8388, 2015.

[36] Y. S. Kim, Y. M. Lee, H. Kim et al., "Anti-obesity effect of Morus bombycis root extract: anti-lipase activity and lipolytic effect," Journal of Ethnopharmacology, vol. 130, no. 3, pp. 621-624, 2010.

[37] N. Mahmood, "A review of $\alpha$-amylase inhibitors on weight loss and glycemic control in pathological state such as obesity and diabetes," Comparative Clinical Pathology, vol. 25, no. 6, pp. 1253-1264, 2016.

[38] D. Kwon, G. D. Kim, W. Kang et al., "Pinoresinol diglucoside is screened as a putative $\alpha$-glucosidase inhibiting compound in Actinidia arguta leaves," Journal of the Korean Society for Applied Biological Chemistry, vol. 57, no. 4, pp. 473-479, 2014.

[39] D. Yang, J. Liang, H. Xie, and X. Wei, "Norsesquiterpenoids and triterpenoids from strawberry cv. Falandi," Food Chemistry, vol. 203, pp. 67-72, 2016.

[40] R. Shukla, S. Gupta, J. K. Gambhir, K. M. Prabhu, and P. S. Murthy, "Antioxidant effect of aqueous extract of the bark of Ficus bengalensis in hypercholesterolaemic rabbits," Journal of Ethnopharmacology, vol. 92, no. 1, pp. 47-51, 2004.

[41] J. J. Kelley and A. C. Tsai, "Effect of pectin, gum Arabic and agar on cholesterol absorption, synthesis, and turnover in rats," The Journal of Nutrition, vol. 108, no. 4, pp. 630-639, 1978.

[42] S. B. Sharma, A. Nasir, K. M. Prabhu, P. S. Murthy, and G. Dev, "Hypoglycaemic and hypolipidemic effect of ethanolic extract of seeds of Eugenia jambolana in alloxan-induced diabetic rabbits," Journal of Ethnopharmacology, vol. 85, no. 2-3, pp. 201-206, 2003.
[43] H. X. Wang and T. B. Ng, "Natural products with hypoglycemic, hypotensive, hypocholesterolemic, antiatherosclerotic and antithrombotic activities," Life Sciences, vol. 65, no. 25, pp. 2663-2677, 1999.

[44] M. C. Fogarty, C. M. Hughes, G. Burke, J. C. Brown, and G. W. Davison, "Acute and chronic watercress supplementation attenuates exercise-induced peripheral mononuclear cell DNA damage and lipid peroxidation," British Journal of Nutrition, vol. 109, no. 2, pp. 293-301, 2013.

[45] F. Zargari, A. Ghorbanihaghjo, H. Babaei, S. Farajnia, and N. H. Roodbari, "The effect of hydroalcoholic extract of Nasturtium officinale R. Br on antioxidant status and DNA damage in liver and kidney rats exposed to arsenic," Medical Journal of Tabriz University of Medical Sciences, vol. 36, no. 3, p. 44, 2014.

[46] N. A. Casanova, M. F. Simoniello, M. M. López Nigro, and M. A. Carballo, "Modulator effect of watercress against cyclophosphamide-induced oxidative stress in mice," Medicina, vol. 77, no. 3, pp. 201-206, 2017.

[47] S. Bahramikia, A. Ardestani, and R. Yazdanparast, "Protective effects of four Iranian medicinal plants against free radicalmediated protein oxidation," Food Chemistry, vol. 115, no. 1, pp. 37-42, 2009.

[48] K. W. Seo, J. G. Kim, M. Park, T. W. Kim, and H. J. Kim, "Effects of phenethylisothiocyanate on the expression of glutathioneS-transferases and hepatotoxicity induced by acetaminophen," Xenobiotica, vol. 30, no. 5, pp. 535-545, 2000.

[49] H. P. Ciolino, P. J. Daschner, and G. C. Yeh, "Dietary flavonols quercetin and kaempferol are ligands of the aryl hydrocarbon receptor that affect CYP1A1 transcription differentially," Biochemical Journal, vol. 340, no. 3, pp. 715-722, 1999.

[50] F. Kassie, B. Laky, R. Gminski et al., "Effects of garden and water cress juices and their constituents, benzyl and phenethyl isothiocyanates, towards benzo(a)pyrene-induced DNA damage: a model study with the single cell gel electrophoresis/ Hep G2 assay," Chemico-Biological Interactions, vol. 142, no. 3, pp. 285-296, 2003.

[51] C. Gerhäuser, M. You, J. Liu et al., "Cancer chemopreventive potential of sulforamate, a novel analogue of sulforaphane that induces phase 2 drug-metabolizing enzymes," Cancer Research, vol. 57, no. 2, pp. 272-278, 1997.

[52] S. Srivastava, S. Mishra, R. D. Tripathi, S. Dwivedi, P. K. Trivedi, and P. K. Tandon, "Phytochelatins and antioxidant systems respond differentially during arsenite and arsenate stress inHydrilla verticillata (L.f.) royle," Environmental Science \& Technology, vol. 41, no. 8, pp. 2930-2936, 2007.

[53] S. Namdjoyan and H. Kermanian, "Exogenous nitric oxide (as sodium nitroprusside) ameliorates arsenic-induced oxidative stress in watercress (Nasturtium officinale R. Br.) plants," Scientia Horticulturae, vol. 161, pp. 350-356, 2013.

[54] J. Xiong, G. Fu, L. Tao, and C. Zhu, "Roles of nitric oxide in alleviating heavy metal toxicity in plants," Archives of Biochemistry and Biophysics, vol. 497, no. 1-2, pp. 13-20, 2010.

[55] T. Hofmann, A. Kuhnert, A. Schubert et al., "Modulation of detoxification enzymes by watercress: in vitro and in vivo investigations in human peripheral blood cells," European Journal of Nutrition, vol. 48, no. 8, pp. 483-491, 2009.

[56] L. A. Boyd, M. J. McCann, Y. Hashim, R. N. Bennett, C. I. R. Gill, and I. R. Rowland, "Assessment of the antigenotoxic, anti-proliferative, and anti-metastatic potential of crude watercress extract in human colon cancer cells," $\mathrm{Nu}$ trition and Cancer, vol. 55, no. 2, pp. 232-241, 2006. 
[57] A. T. Diplock, "Will the "good fairies" please prove to us that vitamin E lessens human degenerative disease?" Free Radical Research, vol. 27, no. 5, pp. 511-532, 1997.

[58] E. F. Lhoste, K. Gloux, I. De Waziers et al., "The activities of several detoxication enzymes are differentially induced by juices of garden cress, water cress and mustard in human HepG2 cells," Chemico-biological Interactions, vol. 150, no. 3, pp. 211-219, 2004.

[59] M. Akbari Bazm, M. Khazaei, F. Khazaei, L. Naseri, and L. Nasturtium Officinale, "Hydroalcoholic extract improved oxymetholone-induced oxidative injury in mouse testis and sperm parameters," Andrologia, vol. 51, Article ID e13294, 2019.

[60] H. Sadeghi, N. Azarmehr, F. Razmkhah et al., "The hydroalcoholic extract of watercress attenuates protein oxidation, oxidative stress, and liver damage after bile duct ligation in rats," Journal of Cellular Biochemistry, vol. 120, 2019.

[61] M. Kapiszewska, E. Soltys, F. Visioli, A. Cierniak, and G. Zajac, "The protective ability of the Mediterranean plant extracts against the oxidative DNA damage. The role of the radical oxygen species and the polyphenol content," Journal of Physiology and Pharmacology Supplement, vol. 56, no. 1, pp. 183-197, 2005.

[62] N. A. Casanova and M. A. Carballo, "Antigenotoxic activity of watercress extract in an in vitro mammalian system using comet assay," Phytotherapy Research, vol. 25, no. 12, pp. 1743-1746, 2011.

[63] N. A. Casanova, J. I. Ariagno, M. M. López Nigro et al., "In vivoantigenotoxic activity of watercress juice (Nasturtium officinale) against induced DNA damage," Journal of Applied Toxicology, vol. 33, no. 9, pp. 880-885, 2013.

[64] N. Casanova, M. Wagner, M. López Nigro, and M. Carballo, "Effect of watercress on induced DNA damage, DNA repair and p-glycoprotein activity in human lymphocytes," BAGJournal of Basic and Applied Genetics, vol. 25, no. 2, 2014.

[65] S. J. Duthie, A. R. Collins, G. G. Duthie, and V. L. Dobson, "Quercetin and myricetin protect against hydrogen peroxideinduced DNA damage (strand breaks and oxidised pyrimidines) in human lymphocytes," Mutation Research/Genetic Toxicology and Environmental Mutagenesis, vol. 393, no. 3, pp. 223-231, 1997.

[66] L. R. Ferguson, S.-t. Zhu, and P. J. Harris, "Antioxidant and antigenotoxic effects of plant cell wall hydroxycinnamic acids in cultured HT-29 cells," Molecular Nutrition \& Food Research, vol. 49, no. 6, pp. 585-593, 2005.

[67] C. Aksornthong, S. Prutipanlai, P. Ruangrut, and B. Janchawee, "Cooking has the potential to decrease the antitumor effect of fresh Betong watercress," Journal of Food Biochemistry, vol. 43, no. 4, Article ID e12783, 2019.

[68] A. R. E. Natanzi, M. H. Ghahremani, H. R. M. Esfehani, M. B. Minaei, H. Nazarian, and O. Sabzevari, "Evaluation of antihepatotoxic effect of watercress extract and its fractions in rats," International Journal of Pharmacology, vol. 6, no. 6, pp. 896-902, 2010.

[69] A. E. Natanzi, M. H. Ghahremani, H. R. Monsef-Esfahani, B. Minaei, H. Nazarian, and O. Sabzevari, "An experimental model for study of the hepatoprotective activity of Nasturtium officinale (Watercress) against acetaminophen toxicity using in situ rat liver system," European Journal of Scientific Research, vol. 38, no. 4, pp. 556-564, 2009.

[70] M. Karami, A. Nosrati, M. Naderi, M. Makhloogh, and S. Shahani, "Protective effects of Nasturtium officinale against gamma-irradiation-induced hepatotoxicity in C57 mice,"
Research Journal of Pharmacognosy, vol. 2, no. 2, pp. 19-25, 2015.

[71] X. Wu, Q.-h. Zhou, and K. Xu, "Are isothiocyanates potential anti-cancer drugs?” Acta Pharmacologica Sinica, vol. 30, no. 5, pp. 501-512, 2009.

[72] A. Kumar, S. S. D'Souza, S. Tickoo, B. P. Salimath, and H. B. Singh, "Antiangiogenic and proapoptotic activities of allyl isothiocyanate inhibit ascites tumor growth in vivo," Integrative Cancer Therapies, vol. 8, no. 1, pp. 75-87, 2009.

[73] H. P. Lee, L. Gourley, S. W. Duffy, J. Estève, J. Lee, and N. E. Day, "Colorectal cancer and diet in an asian populationA case-control study among Singapore Chinese," International Journal of Cancer, vol. 43, no. 6, pp. 1007-1016, 1989.

[74] R. F. Mithen, M. Dekker, R. Verkerk, S. Rabot, and I. T. Johnson, "The nutritional significance, biosynthesis and bioavailability of glucosinolates in human foods," Journal of the Science of Food and Agriculture, vol. 80, no. 7, pp. 967-984, 2000.

[75] D. T. Verhoeven, R. A. Goldbohm, G. van Poppel, H. Verhagen, and P. A. van den Brandt, "Epidemiological studies on brassica vegetables and cancer risk," Cancer Epidemiology, Biomarkers \& Prevention, vol. 5, no. 9, pp. 733-748, 1996.

[76] K. Sakao, A. R. Vyas, S. R. Chinni, A. I. Amjad, R. Parikh, and S. V. Singh, "CXCR4 is a novel target of cancer chemopreventative isothiocyanates in prostate cancer cells," Cancer Prevention Research, vol. 8, no. 5, pp. 365-374, 2015.

[77] M. A. Morse, C. X. Wang, G. D Stoner et al., "Inhibition of 4(methylnitrosamino)-1-(3-pyridyl)-1-butanone-induced DNA adduct formation and tumorigenicity in the lung of F344 rats by dietary phenethyl isothiocyanate," Cancer Research, vol. 49, no. 3, pp. 549-553, 1989.

[78] S. S. Hecht, F. L. Chung, J. P Richie et al., "Effects of watercress consumption on metabolism of a tobacco-specific lung carcinogen in smokers," Cancer Epidemiology and Prevention Biomarkers, vol. 4, no. 8, pp. 877-884, 1995.

[79] P. Rose, Q. Huang, C. N. Ong, and M. Whiteman, "Broccoli and watercress suppress matrix metalloproteinase-9 activity and invasiveness of human MDA-MB-231 breast cancer cells," Toxicology and Applied Pharmacology, vol. 209, no. 2, pp. 105-113, 2005.

[80] D. A. D. Souza, P. M. Costa, R. I. Ribeiro, P. V. Vidigal, and F. C. Pinto, "Daily intake of watercress causes inhibition of experimental Ehrlich tumor growth," Jornal Brasileiro de Patologia e Medicina Laboratorial, vol. 52, no. 6, pp. 393-399, 2016.

[81] R. Moradi, S. Ebrahimi, A. Taravati et al., "Cytotoxic effects of the hydroalcoholic extract of rorippa nasturtium aquaticum on hela cell line," International Biological and Biomedical Journal, vol. 3, no. 2, pp. 73-79, 2017.

[82] F. Campos, H. Pinheiro-Sant'ana, P. Stringheta, and J. Chaves, "Teores de betacaroteno em vegetais folhosos preparados em restaurantes comerciais de Viçosa-MG," Brazilian Journal of Food Technology, vol. 6, no. 2, pp. 163-169, 2003.

[83] P. C. Stringheta, A. M. Nachtigall, Td Oliveira, A. M. Ramos, H. M. P. Sant'ana, and M. P. J. C. Gonçalves, "Luteína: propriedades antioxidantes e benefícios à saúde," Alimentos e Nutrição Araraquara.vol. 17, no. 2, pp. 229-238, 2009.

[84] C. R. d. M. Silva and M. M. V. Naves, "Vitamin supplementation in cancer chemoprevention," Revista de Nutrição, vol. 14, no. 2, pp. 135-143, 2001.

[85] R. Munday, P. Mhawech-Fauceglia, C. M. Munday et al., "Inhibition of urinary bladder carcinogenesis by broccoli sprouts," Cancer Research, vol. 68, no. 5, pp. 1593-1600, 2008. 
[86] S. Shahani, F. Behzadfar, D. Jahani, and F. Shaki, "Protective effects of hydroalcoholic extract of nasturtium officinale against gentamicin induced mitochondrial dysfunction in rat kidney," Journal of Mazandaran University of Medical Sciences, vol. 26, no. 145, pp. 152-164, 2017.

[87] S. Mehrabi, E. Askarpour, F. Mehrabi, and R. Jannesar, "Effects of hydrophilic extract of Nasturtium officinale on prevention of ethylene glycol induced renal stone in male Wistar rats," Journal of Nephropathology, vol. 5, no. 4, pp. 123-127, 2016.

[88] A. Davidson, The Oxford Companion to Food, OUP Oxford, Oxford, UK, 2014.

[89] U. Justesen and P. Knuthsen, "Composition of flavonoids in fresh herbs and calculation of flavonoid intake by use of herbs in traditional Danish dishes," Food Chemistry, vol. 73, no. 2, pp. 245-250, 2001.

[90] M. Karami, M. Mostafazadeh, H. Sadegh et al., "Nephroprotective effect of nasturtium officinale (watercress) ethanol extract and vitamin $\mathrm{E}$ on vancomycin-induced nephrotoxicity in Ra," Jundishapur Journal of Natural Pharmaceutical Products, vol. 13, 2017.

[91] H. Sadeghi, M. Mostafazadeh, H. Sadeghi et al., "In vivoantiinflammatory properties of aerial parts ofNasturtium officinale," Pharmaceutical Biology, vol. 52, no. 2, pp. 169-174, 2014.

[92] C. Camponogara, C. R. Silva, I. Brusco et al., "Nasturtium officinale $\mathrm{R}$. Br. effectively reduces the skin inflammation induced by croton oil via glucocorticoid receptor-dependent and NF- $\kappa \mathrm{B}$ pathways without causing toxicological effects in mice," Journal of Ethnopharmacology, vol. 229, pp. 190-204, 2019. 